\title{
GUIDE TO THE INTERNATIONAL ARCHIVES AND COLLECTIONS AT THE IISH: SUPPLEMENT FOR 201 $3^{*}$
}

In 2000 a revised edition of the 'Guide to the International Archives and Collections at the IISH, Amsterdam' (henceforth cited as GIA) was published. Since then, a description of recently acquired archives and collections as well as major accruals to archives kept by the IISH have been published annually to keep this guide up to date. Like the GIA this supplement is subdivided into the categories: 'persons', 'organizations', and 'subjects', arranged alphabetically.

Each entry gives a summary which consists of the following components:

I. Access: As a rule consultation is not restricted; any restrictions are indicated by *

2. Name: Names of persons include dates of birth and death when known. In the case of international organizations with names in more than one language, the name chosen corresponds to the language in which most of the documents were written. Among organizations that have changed their names, the one used most recently was selected. Previous names of organizations are mentioned in the condensed biography or history. The names of subject collections are mostly in English.

3. Period: First and last date of the documents present. Where only a few documents are from a certain year or period, they are listed between parentheses.

4. Size: In linear metres.

5. Finding aid: Available inventories, lists and indexes.

6. Biography/history: A condensed biography or history of the persons or organizations concerned.

7. Summary of the contents: A summary of the contents of the archives, papers, or collection concerned.

In case of an accrual to existing archives reference is given to the pages of the GIA containing the initial description.

The summaries of this supplement will also be added to the survey of archival collections on the internet website of the IISH (http://www.iisg.nl). Summaries of the Dutch collections of the IISH can be found in the survey on the internet website too.

The archives may be consulted in the reading room of the IISH. Requests for documents should include their inventory or list numbers. For further information about the rules for access and consultation (including rules on procedures for handling the material and making photocopies) users should contact the information service of the IISH (e-mail: ask@iisg.nl). 


\title{
I. Persons
}

\author{
Auzias, Claire (born 1951) \\ Period: $1977-1980$ \\ Size: $0.12 \mathrm{~m}$.
}

Accrual: For initial description see GIA, p. 35 .

Photocopies from transcriptions of interviews held by Claire Auzias with Louis Buronfosse 1977, Marius Chabany 1977, Antoine Marsella and Marie-Louise Marsella-Massoubre 1977, I980, Pierre Masneuf I978, and Lorenzo Ruiperez I977, 979.

\section{Bedford, Michael (born 1946) \\ Period: 1982-I99I \\ Size: 56 audiocassettes and c.I 75 photos}

Finding aid: list

Born in Bryn Mawr, Pennsylvania, USA 1946; lived and worked in the Philippines 1970-1972, 1975; involved in the anti-Marcos movement that centred on US involvement in Philippine politics; interviews were conducted by Bedford over the course of 1986-1990; purpose of the research was to understand the political changes occurring in the post-Marcos martial law period, and especially on the growth of the 'Legal Left' (the NGOs), the liberation theology arm of the Roman Catholic Church on one side, and the conservative Roman Catholic Church, the rise in US Protestant missionaries, and corresponding growth of local anti-communist organizations under the name of Christ on the other; the Philippines witnessed arson of churches, civilian executions, and assassination of legal left leaders across the country; later on Bedford was founder of Third World Reports, conducting media fact-finding missions to the Philippines, Pacific and Haiti, 1984-1991, Asia Regional Manager of Oxfam America 1991-1999, Bangladesh Country Director of the US Peace Corps 2000-2002, Asia Regional Director of Right to Play 2005-2009, Executive Director of Volunteers in Asia 2009-20I I and from 20I I Adjunct Faculty at Lesley University in North Adams, Massachusetts.

Fifty-six audiocassettes with interviews held by Michael Bedford mainly in the years I 986-I990 on the political situation in the Philippines during the first years of the Aquino government (1986-I992) and several other subjects; interviews are with Leon Alejandro, Jean-Bertrand Aristide, Levy Bautista, Bernabe Buscayno, Renato Constantino, José Diokno and his daughter Maris, Roland Simbulan, José Sison, Jimmy Tadeo, Gavino Tica and others; about I75 photographs of demonstrations and protest meetings of various parties and groups to the left and to the right of the political spectrum in the Philippines I982-I991.

\section{Fanggidaej, Francisca C. (1925-2013) \\ Period: 1962-2013 \\ Size: $\mathbf{2} \mathbf{~ m}$.}

Born in Noelmina near Koepang, Timor, Netherlands East Indies 1925 , died in Utrecht, the Netherlands 2013; teacher, interpreter, and journalist; married to Sukatno, board member of the Pemuda Sosialis Indonesia (Pesindo), the Socialist Youth of Indonesia, I 948; second marriage to the journalist Soepriyo; during the independence struggle journalist for Radio Gelora Pemuda Indonesia; became a member of Pesindo 1945; travelled to Europe as a delegate of Pesindo 1947; the Pesindo congress of 1950 established ties with the PKI, the Indonesian Communist Party, changed its name in Pemuda Rakyat, and Fanggidaej became its chairwoman; became a 
representative of the journalists to the Indonesian People's Representative Council; visited Cuba 1960 and 1963 as a delegate of the Indonesian Parliament; advisor to President Sukarno during his state visit to Algeria 1964; member of the Indonesian delegation to a congress of the International Organization of Journalists in Chile 1965; returned after the coup d'état of 30 September 1965 to Jakarta but was advised to leave the country immediately; lived since then about twenty years in China and since 1985 in the Netherlands; member of the board of the Dutch Indonesia Committee and co-founder of the Asian Studies Foundation; central to the network of Indonesian refugees in the Netherlands.

Agenda and notebooks I985-20I3; correspondence with family members I965-1988 and especially with 'Doortje' who took care of her children in Indonesia after her forced departure 1965-1973; correspondence with comrades in exile 1966-1998, for instance with Agam Wispi 1985-1986; correspondence with a.o. Hersri Setiawan, Dick Soekardiman, W.F. Wertheim, Anne-Ruth Wertheim, and the Dutch Indonesia Committee; typescripts and articles on the political and social situation in Indonesia, especially the position of prisoners and women I966-2009; typescript of a speech by Mrs Subandrio 1962; file on the Tricontinental Conference in Havana, Cuba, in January 1966 and the contribution of the Indonesian delegation I966; file on recognition as a refugee in the Netherlands 1985-1990; plea of Hartono Dharsono 1986.

\section{Fontanillas, Antonia (born 1917) \\ Period: 1937, 1949-2013 \\ Size: $2.25 \mathrm{~m}$.}

\section{Finding aid: inventory}

Accrual: for initial description see GIA for 2004, p. 347.

Correspondence with Ramón Alvarez 1978-200I, Sara Berenguer and Jesús Guillén 1977-2010, Lola Iturbe and Juan Molina and other family members I977-201 I, Manuel and Pilarín Llatser 1954-2002, Laieta Pajerols and Emilio Vilardaga I953-1991, and others; correspondence with persons and institutions in Paris I99I-20I3; correspondence with universities, researchers, and publishing houses in Andalusía, Barcelona, Madrid, Valencia, and other parts of Spain, other European countries, and Latin America 1989-2009; correspondence with women on mujeres issues I99I-20II; correspondence with the Centre International de Recherches sur l'Anarchisme (CIRA) and other documentation centres I959-20I I; correspondence with and documents from the CNT de España en el exilio, the Federación Ibérica de Juventudes Libertarias (FIJL), and the Federación Anarquista Ibérica (FAI) I949-I98 I; correspondence with the Confederación General del Trabajo (CGT) I99I-20I 3; files on congresses and committees of CNT/CGT 1977-2008; files on the Movimiento Libertario Español (MLE) in France 1955-1994; documents from and on various institutions and activities of the Spanish Republic I937.

\section{L'Aminot, Tanguy (born 1948)}

Period: 1972-2009

Size: $0.12 \mathrm{~m}$.

Finding aid: inventory

Born in Voiron, Isère, France 1948; researcher at the French National Center for Scientific Research (CNRS) at the Sorbonne, responsible for a research programme on Jean-Jacques 
Rousseau; founder in 1987 and editor of the periodical Les Études Jean-Jacques Roussean; published several books on Rousseau like Images de Jean-Jacques Rousseau de $19 I 2$ à 1978 (Oxford, 1992).

Correspondence 1972-2009; most letters received by L'Aminot in 1977-1978 are answers to a survey by L'Aminot on the image of Jean-Jacques Rousseau in libertarian circles; the results are published in Les Etudes Jean-Jacques Roussean 1987-1988; especially the correspondence with Roger Dorey, a retired factory worker in Lyon and an 'anarchiste individualiste', covers a longer period of time I976-2004.

\section{Mattick, Paul (1904-I98I) \\ Period: 1930-I98I (-I99I) \\ Size: $0.37 \mathrm{~m}$. \\ Finding aid: list}

Accrual: for initial description see GIA, pp. I48-I49.

(Photocopies of) letters from Paul and Ilse Mattick to Claudio Pozzoli I968-I978; (photocopies of) correspondence between Mattick and Uli Bohnen 1972-1980, Volkhard Brandes 1974-1975, Serge Bricianer 1970-1974, Michael Buckmiller I972-I980, Walter Fähnders I97 I-I972, Leif Hansen I973-I980, Preben Kaarsholm I973-I980, Joyce and Gabriel Kolko I968-1979, Fairfield Porter 1938-1941, Finn Dam Rasmussen 1977-1978, Naomi Sager 1958-1960, Tilla Siegel 1973-1980, David Yaffe 197I-I975; letter of Hans F. Schaper to the editors of the journal Internationale wissenschaftliche Korrespondenz zur Geschichte der deutschen Arbeiterbewegung $(I W K)$ regarding Frank Dingel's article on Paul Mattick I991; files on interviews by Claudio Pozzoli and Peter von Spall with Mattick 1972 and n.d.; photocopies of articles by Mattick in Mitteilungsblatt des Arbeiter Kultur-und Sport-Kartells and Worker's League News 1930-1933.

\section{Moneta, Jakob (I9I4-2012) \\ Period: $1960-2010$ \\ Size: $11.75 \mathrm{~m}$.}

Pseudonym Anna Armand; born in Blasow, Austria-Hungary I9I 4, died in Frankfurt am Main, Germany 20I 2; German journalist, trade-unionist, and politician; his family fled to Cologne after a pogrom I9I9, where his father, a textile manufacturer, was born; Jakob grew up in Cologne; joined Hashomer Hatzair, a Socialist-Zionist youth movement, affiliated with the International Falcon Movement I93 I, and a few months later the Sozialistischer Jugendverband, the youth organization of the Sozialistische Arbeiterpartei Deutschlands (SAPD); became acquainted with SAP-founder Hans Mayer who aroused his interest in the writings and ideas of Trotsky; emigrated to Palestine at the end of 1933 and lived there in a kibbutz; organized as orange labourer union strikes for the eight-hour workday and the necessity of a common struggle of Jewish and Arab workers; entered into conflict and left the kibbutz 1939; interned for twenty-seven months by the British authorities because of his activities; organized a prison university and collaborated after his release with left-wing Arabs; returned to Cologne, where he became a member of the Internationale Kommunisten Deutschlands (IKD), the German section of the Fourth International 1948; editor of the SPD-oriented daily Rheinische Zeitung, led by Willi Eichler and Heinz Kühn, 1948-1953; referent for social issues at the German embassy in Paris, secretly engaging with the Algerian liberation movement FLN 1953-1962; 
returned to Cologne and became chief editor of Metall and Der Gewerkschafter, magazines of the IG-Metall trade union in the FRG 1962-1978; member of the Gruppe Internationale Marxisten (GIM) since 1969 and after the fusion with the KPD/ML of the Vereinigte Sozialistische Partei (VSP); excluded from the SPD 1990; active member of the Partei des Demokratischen Sozialismus (PDS) and board member until 1995; published also in the SoZ Sozialistische Zeitung and in Der Tagesspiegel and the Jüdische Allgemeine; Moneta was married to Siglinde 'Sigi' Lange, born in Lichtenstein, Saxony, Germany 1932 and died in Frankfurt am Main 2002.

Correspondence 1978-2007; lectures 1967-1999; file on the committee that aimed at lifting the entry ban to the FRG imposed on Ernest Mandel 1976-1977; file on the committee for the release of Rudolf Bahro, including a letter from Freddy Olsson to Wolf Biermann 1978; file on the situation in Poland 198I; files regarding the Hamburger Institut für Sozialforschung, including correspondence with Ernest Mandel and Alice Schwarzer I983-1986; files regarding the Gruppe Internationale Marxisten (GIM) and their internal periodicals I984-I988, the Vereinigte Sozialistische Partei 1987-1989 and the Partei des Demokratischen Sozialismus 1990-1996; files on the 80th and 90th birthday of Moneta 1994, 2004; correspondence with the family of his wife living in the GDR I960-200I; file on illness and death of Sigi Moneta 2002.

\section{Sabatier, Guy (born 1947) \\ Period: 193 I-2010 \\ Size: $2.5 \mathrm{~m}$.}

\section{Finding aid: inventory}

Born in Alès, France 1947; came into contact with the labour movement during the strikes in Clermont-Ferrand, the industrial city of the Auvergne 1968; involved in this city in the formation of the Mouvement d'Action Révolutionnaire Spontanée (MARS) and later on in the Organisation Conseilliste; joined the organization Information Correspondance Ouvrière (ICO), initiated by the French militant Marxist Henri Simon with the support of the French militant communist Gaston Davoust (Henry Chazé); left the ICO in the course of confrontations between an Anarchist-Situationist tendency and Marxist factions I970; a reunification of the latter took place as the Courant Communiste International (CCI) issuing the periodical Révolution Internationale Nowvelle Série 1972; in 1974 Sabatier and two comrades initiated the group Pour une Intervention Communiste (PIC) with the periodical Jeune Taupe, which would remain active until $198 \mathrm{I}$, with Gaston Davoust in the background; the strikes of Polish workers of Solidarność in 1980-I98I caused another split-off resulting in the foundation of the group Volonte Communiste, with the magazine Révolution Sociale; in an effort to establish a dialogue between Marxists and Anarchists the Comité d'Organisation des Journées de Réflexion Anti-Autoritaires (COJRA) was formed; supported also the review Perspective Internationaliste; after 2000 Sabatier associated himself with the Cercle de Paris and magazine Le Prolétaire Universel; the economic crisis of 2008 led to an orientation towards the Forum de la Gauche Communiste Internationaliste and its review Controverses, issued since 2009 .

Letters from Michel Besson, Jean-Luc Garioud, Emilio Madrid Exposito, Joaquin Sirera and others I969-2004; a file on Gaston Davoust (Henry Chazé) including letters sent by Marie-Louise Berneri, Daniel Kolko, Piere Laste, André Prudhommeaux, Ruth Sheridan, and others to Davoust, an extensive correspondence with 
Guy Sabatier and documents relating to Davoust's political career 1935-I986; typescripts by and on Jean Malaquais 1999-2010; correspondence with James Schenkel and pamphlets relating to his dismissal at the Peugeot motor works 1978-1986; leaflets and tracts from local councilist organizations in Clermont-Ferrand 1969-I974; (internal) documents of the group Pour une Intervention Communiste (PIC) and the review Jeune Taupe 1974-1985 and the Spartacus publishing house 1978-1987, documents on the Comité d'Organisation des Journées de Réflexion Antiautoritaire (COJRA) 1982-1987 and the Groupe Volonté Communiste and their magazine Révolution Sociale 1981-1987; notes and sketches for his book Traité de Brest-Litovsk 19I8. Coup d'arrêt à la révolution 1973-1977; notes and outline for an unfinished study on Leo Jogiches including correspondence with Heinz Meyer, Jean-Pierre Le Nir and others on this project I98 I-I986; leaflets and bulletins from French organizations like Groupe Communiste L'Eveil Internationaliste and Spanish collectives like Col.lectiu de Sant Pau and No Afiliados I976-I981; a large number of bulletins from various French leftist organizations, many pamphlets from French, Spanish, Portuguese and Italian organizations 1964-2002.

\section{Organizations}

\section{CNT Federación Regional Cantabria}

Period: (1937-1940), 1964-1970

Size: $0.25 \mathrm{~m}$.

Finding aid: list

In 2012 the IISG acquired the archives of the CNT Federación Regional Cantabria. See GIA for 2012, pp. 389-390. In 2013 the IISH acquired the archives of one of its predecessors, the Montañesa. In the second half of 1960 the Comisión Nacional de Relaciones was founded in Cantabria to reorganize the CNT; the goal was to stimulate the end of the Franco dictatorship; the name of the regional federation was first 'Comarcal Montañesa', later 'Regional Montañesa' and from 1976 'Regional (de) Cantabria'.

Personal papers of Jesús Ramos García (1937-1940), 1966-1969; correspondence between Jesús Ramos García and Roque Santamaría 1965-1969; correspondence and other documents from and to members and sympathizers of the CNT in Paris and Toulouse, France 1965-1969; correspondence and other documents from and to members and sympathizers of the CNT in towns and regions as Andalusía, Asturias, Barcelona, Bilbao, the Levante, Madrid, and Zaragoza, Spain 1965-1970; documents on La Alianza Sindical Obrera, the Unión General de Trabajadores de España and other organizations $1965-1970$.

\section{European Conference/Council of Conscripts Organizations (ECCO) Period: (1976-) 1979-2005 \\ Size: $3.75 \mathrm{~m}$.}

\section{Finding aid: inventory}

Broadly representative platform for conscripts' movements in Europe; founded in Malmö, Sweden, by a group of conscripts from several European countries as the European Conference of Conscripts Organisations (ECCO) 1979; the name was changed to European Council of 
Conscripts Organisations (ECCO) I992, when the loose platform became an association; international non-governmental youth organization working to promote the recognition of the basic human rights of young people performing compulsory military service, safe working and living conditions, fair legal procedures and acceptable social and economic conditions; these demands were formulated in the European Social Charter for Conscripts; ECCO, starting in western and northern Europe, had the ambition of playing an active role in bringing the western and eastern parts of Europe closer together; had at its peak eleven member organizations from eleven European countries; acquired observer status in the European Youth Forum and the European Co-ordination Bureau of International Youth Organisations (ECB) I998; based in Utrecht (1979-1998) and Stockholm (1998-2005).

Documents on the ECCO congresses 1979-2000; minutes of the meetings of the Executive Committee 1995-2002; correspondence I991-2005; files on the founding and organization 1992-200I; files on the financial administration 1995-2004; files on the contacts with youth and other organizations concerning conscripts and the European Social Charter for Conscripts 1976-2003; publications 1985-1999; photographs i986-i 997 .

\section{*International Confederation of Free Trade Unions (ICFTU) \\ Period: I949-I 993 \\ Size: $345.62 \mathrm{~m}$.}

Finding aid: list

Accrual: for initial description see GIA, pp. 282-284.

Files on the founding and the constitution of the ICFTU 1949-1957; files on the 35 th anniversary in 1984 and the 40 th anniversary in 1989; files on social issues and the meetings of the Social Committee I976-I992; files on women's issues and the meetings of the Women's Committee r968-1989; files on youth and young workers 1973-1989; files on various International Trade Secretariats (ITS) I950-1988, especially on diamond workers I950-1976; files on the African Regional Organisation (AFRO) I959-1985, the Asian Regional Organisation (ARO) 1975-1983 and the Organización Regional Interamericana de Trabajadores (ORIT) I969-I986; files on African countries like South Africa I969-I989 and Rhodesia/Zimbabwe I974-I983; files on Asian countries such as India 1968-1986 and Indonesia 1958-1986; files on Caribbean and Latin American countries such as Argentina 1958-1989, Chile I974-1985, Cuba 1960-1986, El Salvador 1976-1987, and Nicaragua 1976-1985; files on European countries such as Poland I982-I988, Portugal I974-I98I, and Spain I97I-I987; files on UNESCO I967-I988.

\section{International Working Men's Association (IWMA) \\ Period: 1933 \\ Size: $0.02 \mathrm{~m}$. \\ Finding aid: inventory}

Accrual: for initial description see GIA, pp. 297-298.

Typed draft minutes (including a series of handwritten notes), in French, of the International Conference of the IWMA in Amsterdam from 22-24 April 1933; 
typescript 'Die Lage in Deutschland' on the situation in Germany in 1933; typescript 'Against Fascism'. Declaration by the Anti-Fascist Labour Congress of the IWMA in Paris June I933; two documents on the loss of the archives of the IMWA by Augustin Souchy.

\author{
*Karen National Union (KNU) \\ Period: 1967-2002 \\ Size: $15 \mathrm{~m}$.
}

Finding aid: list

The Karen National Union (KNU) is a political organization representing the aspirations of the Karen people; it is estimated that there are approximately 7 million Karen people in Burma; the KNU was founded in 1947; from 1949 on there was an armed struggle against the central regime; at first the aim was independence but since 1976 the armed group has called for a federal system rather than an independent Karen State; in January 2012 Burma's government signed a ceasefire deal with the KNU and since then peace talks have been going on.

General information 1967-200I; minutes of the meetings of the Standing and the Executive Committee of the KNU I980-I995; documents on the KNU congresses I970-2000; annual reports I980-I990; files of the General Secretary I98I-200I; files on the Central Department/Supreme Headquarters (SHQ) I979-200I; files on the General Staff Headquarters/Karen National Defence Organization (KNDO) I978-200I; files on districts I978-200I; files on the contacts with All Burma Students' Democratic Front (ABSDF) 1988-1994, All Burma Young Monks' Union (ABYMU) I99I, Democratic Alliance of Burma (DAB) I987-200I, National Democratic Front (NDF) I98I-2000, National Health and Education Council (NHEC) 200I-2002, National Coalition Government - Union of Burma (NGCUB) I99I-200I, and National Council of the Union of Burma (NCUB) I $993-2002$.

\author{
People's Russian Information Bureau \\ Period: 1916-1919 \\ Size: $0.02 \mathrm{~m}$.
}

Finding aid: list

The People's Russian Information Bureau in London was founded in 1918 by socialists from various groups, such as Sylvia Pankhurst (Workers' Suffrage Federation) and Shapurji Saklatvala (Independent Labour Party), to supply information on the developments in Russia and the work of the Soviets, in particular on the methods of the opponents of the Bolsheviks and on economic reconstruction under the Soviet regime.

Collection of documents on the activities of the People's Russian Information Bureau: circular letters, brochures, newspapers, and other documents on the situation in Russia and the peripheral areas of the Russian Empire, later the Soviet state, in particular on the struggle between the Bolsheviks and their political opponents, the decline and reconstruction of the Russian economy and the massacre of the Armenian population during the war in the Caucasus i9i6-i9i9.

NB: These documents are part of the collection 'Great Britain, various manuscripts'. 


\author{
Sozialistische Monatshefte - Joseph Bloch (I87I-1936) \\ Period: I 896-1910 \\ Size: $0.5 \mathrm{~m}$.
}

Finding aid: inventory

Accrual: for initial description see GIA, p. 440.

Letters to Joseph Bloch from Eduard Anseele I896-1907, Leo Arons I906-1910, Ignaz Auer I90I-I910, Eduard Bernstein I90I-1910, Hjalmar Branting I906-1907, Martin Buber 1906, Magnus Hirschfeld 190I-1904, Gustav Landauer I899-1904, Max Liebermann 190I, Wilhelm Liebknecht I898, Felix Linke 1907-1910, Joseph Lux 1907-1910, Rosa Luxemburg 1897-1899, Heinrich Mann 1905, Julius Motteler 1903, Fausto Pagliari 1907-1910, Engelbert Pernerstorfer 1906-1910, Adelheid Popp 1906-1907, Georges Sorel I 897-1 898, Emile Vandervelde I897-1901, Willem Vliegen 1901, Georg von Vollmar I898-190I, Clara Zetkin I897-1900 and others.

NB: This part of the Sozialistische Monatshefte archives was salvaged in 1945, kept by the Geheimes Staatsarchiv in Berlin-Dahlem and from 1969 in the Bundesarchiv, and returned to the IISH in 2013 . The main part of the archives of this periodical was transported to Moscow after the end of World War II, kept by the Osoby Archive, and returned to the IISH in 2002.

\title{
World Social Forum (Tunis)
}

Period: 2013

Size: $0.12 \mathrm{~m}$.

Accrual: for initial description see GIA for 201 I, p. 355 .

Daily forum programmes, leaflets, and small print of various organizations present at the Forum in Tunis 20I3.

\section{Subjects}

\section{*iLaw: Internet Dialogue on Law Reform}

Period: $2005-2012$

Size: $0.5 \mathrm{~m}$.

Finding aid: list

In Thailand some trials were held on the accusation of offending against Sections I I 2, 206, and 2 Is of the Criminal Code, offending the Computer-Related Crime Act of 2007 (CCA), and offending against the Radio Communication Act of 1955; these trials were discussed in the context of an Internet Dialogue on Law Reform.

Photocopies of a collection of court documents, police documents, and other documents on trials held in Thailand, on the accusation of offending against Sections I I 2, 206, and 2 Is of the Criminal Code, offending the Computer-Related Crime Act of 2007 (CCA), and offending against the Radio Communication Act of 1955 , collected in the context of an Internet Dialogue on Law Reform 2005-20I 2. 


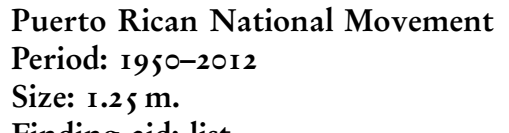

Finding aid: list

Because of the socio-economic and political situation in Puerto Rico many Puerto Ricans migrated to the United States; in November 1950 the Puerto Rican Oscar Collazo López (1914-1994) physically attacked US President Harry Truman in Washington DC; he was jailed for twenty-nine years and was released by US President Jimmy Carter I979 after an ever-increasing campaign; in the I960s the movement of The Young Lords, a group of about 350 Latino residents of Chicago, organized meetings and demonstrations, sometimes in collaboration with the Black Panthers; the Young Lords were in a regular conflict with the police and other representatives of the authorities; in 1969 the Young Lords expanded their activities to New York where a lot of Puerto Ricans live; in 1995 started the Lincoln Park Project, which aimed to archive and document Young Lords' history and the history of the complete displacement of Puerto Ricans, Latinos, and the poor of Lincoln Park; in $20 \mathrm{I} 2$ a theatre project with the play 'Party People' was developed by the Universes Theatre Company.

Correspondence, leaflets, and press-clippings on the Puerto Rican Independence Movement, the Puerto Rican community in the United States, the situation of human rights in Puerto Rico, and Puerto Rican music and culture 1976-1988; documents on the FBI, the Counterintelligence Program (Cointelpro), the situation of Puerto Rican prisoners in prisons in the United States, and the assassination of Ángel Rodríguez Cristóbal 1979 in the federal penitentiary in Tallahassee, Florida in I979-I988.

Collection of letters, photocopies of the trial of Oscar Collazo López and FBI reports, printed materials like brochures, newspapers, and periodicals on the attack, the trial, the commemoration of Collazo's birthday and his eventual release, and the attack by Rafael Cancel Miranda and others on the United States Capitol building in March I954; also more general material on Puerto Rico, the struggle for independence, the aftermath of various uprisings, the situation of political prisoners past and present, and the lives of Puerto Ricans in the United States and on the island I950-1979; photographs, CDs, and DVDs which include an interview in 20 I 2 by Ira Goldwasser and Harriett Broekman with Carmen Zoraida Collazo, the only daughter of Collazo.

Collection of photocopies of documents from and on Young Lords, their founder José (Cha-Cha) Jiménez (born I948), and their collaboration with the Black Panthers and other radical groups 1969-1972; photocopies of articles on the history of Puerto Ricans in the United States, the Young Lords and the Young Lords Party 2007-20I I. 